\title{
Program Corporate Social Responsibility Pertamina Aviation Hang Nadim "Desa Berdikari" in Batam
}

\author{
Alexius \\ Public Administration - Riau University (email: alexius0428@gmail.com) \\ Dadang Mashur \\ Dedi Kusuma Habibie
}

\begin{abstract}
The purpose of this article is to frame the specific role of corporate social responsibility (CSR) by taking of regional potential development through Pertamina Aviation Hang Nadim Batam. The implementation of this corporate social responsibility (CSR) activity was carried out by Pertamina Aviation Hang Nadim of Batam. Pertamina implements corporate social responsibility (CSR) activities for people, planet, and profit purposes. During the period of June 2017-June 2018, this activities has relized 4 (four) CSR activites with the main headline "Desa Berdikari" all of which were held in Batu Besar Village, Nongsa District in Batam. The impact of this CSR activities is to reduce the number of youth dropping out of school, unemployment, as well as an increase in income, and a decrease in the number of malnutrition under-five. This article is the result of research conducted with qualitative with a describtion approach.
\end{abstract}

\section{Keywords :}

Corporate social responsibility (CSR); Pertamina Aviation Hang Nadim; “Desa Berdikari”

\section{Introduction}

Corporate Social Responsibility (CSR) program is now regarded as one of innovation in improving the welfare of society (Nainggolan, A. F., and Rusli, Z., 2015). In terms of Corporate social responsibility (CSR) is an activity carried out by companies as a form of their responsibility towards the surrounding social / environment. The Corporate social responsibility (CSR) program aims to develop the potential in each region. The development of potential in each region is not only the responsibility of the government and industry, but every human being whose role is to create social welfare and manage the quality of life of the community. The need to implement the right CSR strategy to carry out Corporate Social Responsibility actions to encourage regional development (Garcia, 2018). Industry and corporations have a role to promote healthy economic growth by considering environmental factors. According to Elkington, quoted by Mashur (2019), now the business world is no 
longer only paying attention to the corporate's own financial records (single bottom line), including social, economic, and environmental aspects (triple bottom line), the synergy of these three elements is key from the concept of sustainable development.

The policy of the Government of the Unitary State of the Republic of Indonesia which issued Law Number 40 of 2007 concerning Limited Liability Companies, which in article 74 contains provisions concerning "the corporate carrying out its business activities in the fields and / or relating to natural resources to carry out Social and Environmental Responsibility" Then the government issued Government Regulation Number 47 of 2012 dated April 4, 2012 concerning Social and Environmental Responsibility of Limited Liability Companies as the implementing regulation, then based on the Batam City Regional Regulation Number 2 of 2012 concerning corporate social responsibility in Batam City; that the implementation of sustainable development as an effort to realize the welfare and prosperity of the community and the preservation of environmental functions in the Batam City area is an integral part of the implementation of the Batam City Regional Government whose implementation guidelines are contained in Batam Mayor Regulation Number 18 of 2017.

In response to the policy, PT. Pertamina as one of the state-owned national energy companies in Indonesia, which runs its business related to natural resources, has contributed to implementing this policy through its corporate social responsibility (CSR) program. Local government intervention is needed to coordinate and optimize CSR programs by forming regulations related to CSR to ensure the effectiveness of the CSR program and to achieve the goals of both parties, namely the corporate and the local government (Sukmana, 2019).

According to Wirawati (2019), one of the non-financial factors that can affect corporate value is disclosure of Corporate Social Responsibility (CSR). Pertamina manages CSR programs including the Community Development (BL) program and the Partnership Program (PK). The strategic objective of Pertamina's CSR program is to improve Pertamina's reputation and credibility through CSR activities that are integrated with business strategies. To realize this goal, Pertamina implements major strategies, such as:

1. Mutual benefit (fair shared value)

2. Sustainability

3. Priority of operating area and affected area

4. Development of green energy as a responsibility for the impact of operations 


\section{Effective dissemination and publication}

Pertamina's commitment in implementing Social and Environmental Responsibility (TJSL) is manifested in various CSR activities that cover the fields of education, health, environment, infrastructure, community empowerment, disaster management, and special assistance. The realization of these activities is carried out by all Pertamina's CSR work units, both at the head office, operating units and subsidiaries such as Pertamina Aviation Hang Nadim Batam with the title "Desa Berdikari". Pertamina carries out these CSR activities for social, environmental and economic interests (3P). This target is the focus of Pertamina's concern for environmental sustainability, especially the earth for the interests of now and future generations (Mashur, 2019).

\section{Figure 1.}

\section{Pertamina Aviation Hang Nadim Batam}

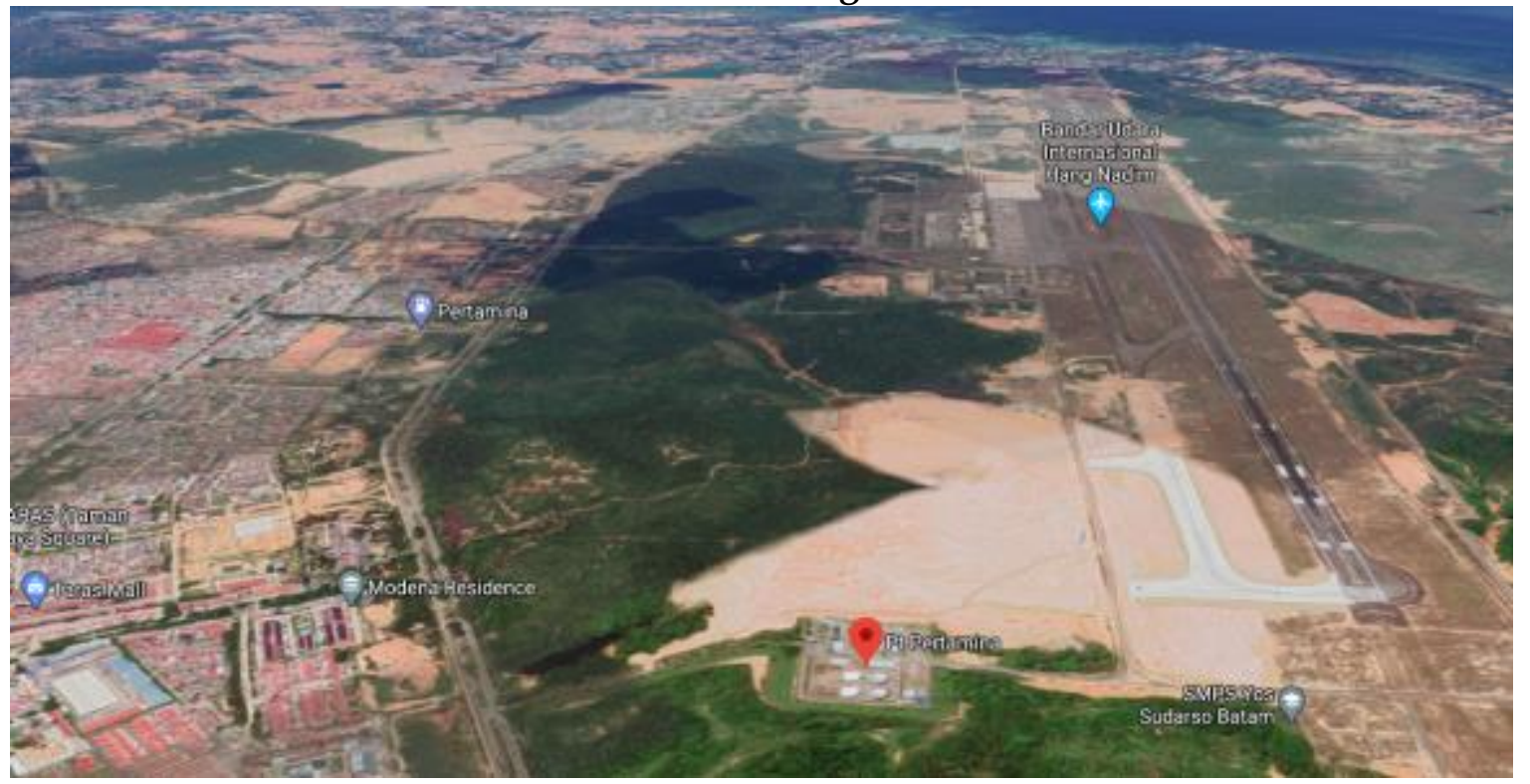

(Source: $h$ ttps://goo.gl/maps/yZLeDJN7mSZtiKCT8)

In line with that in its commitment to implementing CSR, Pertamina Aviation Hang Nadim Batam in synergy with Rumah Zakat conduct social mapping. The term CSR by the corporate is a form of the corporate's commitment to building a better quality of life with related stakeholders, especially the community around the corporate (Anto, 2018). Rumah Zakat is a philanthropic institution that manages zakat, donations, alms and other social funds through community empowerment programs. In initiating all of these series of programs, Rumah Zakat first conducts program planning studies through social mapping, which prioritizes the active role of community participation in exploring local 
potentials in the area, then reports back to Pertamina Aviation Hang Nadim Batam. The following is a table of potential development :

Table 1.

Identification the potential of Batu Besar Village, Nongsa District in Batam

Kind of potential Present condition Development opportunities

\begin{tabular}{|c|c|c|}
\hline Human resources & $\begin{array}{l}\text { The current condition of the } \\
\text { human resources in Batu Besar } \\
\text { Village is quite a lot, except that } \\
\text { they are not skilled human } \\
\text { resources and have low } \\
\text { educational backgrounds. }\end{array}$ & $\begin{array}{l}\text { Skills training needed by the world } \\
\text { of work or entrepreneur-ship } \\
\text { training. }\end{array}$ \\
\hline \multirow{4}{*}{ Natural resources } & $\begin{array}{l}\text { Has an area that includes land } \\
\text { and sea. }\end{array}$ & $\begin{array}{l}\text { It is well managed and becomes a } \\
\text { potential marine and tourism } \\
\text { resource. }\end{array}$ \\
\hline & Gonggong. & $\begin{array}{l}\text { Gonggong as an icon of the Riau } \\
\text { Islands was appointed and } \\
\text { developed with a concept One } \\
\text { Village One Product (OVOP), apart } \\
\text { from being a typical culinary dish, } \\
\text { its shell waste is also developed as } \\
\text { unique and beautiful handycraft so } \\
\text { it has a selling point. }\end{array}$ \\
\hline & Coconut. & $\begin{array}{l}\text { MSME product development with } \\
\text { the OVOP concept of diversified } \\
\text { processed coconut and its } \\
\text { derivatives. }\end{array}$ \\
\hline & Sand and Bauxite. & $\begin{array}{l}\text { As raw material for brick, ceramics } \\
\text { and quality materials with mining } \\
\text { and responsible management. }\end{array}$ \\
\hline $\begin{array}{l}\text { Social and Cultural } \\
\text { resources }\end{array}$ & $\begin{array}{l}\text { The number of social } \\
\text { communities that are close and } \\
\text { active. }\end{array}$ & $\begin{array}{l}\text { The existing social community is } \\
\text { fostered to be more concerned and } \\
\text { synergized in advancing Batu Besar } \\
\text { Village, especially Kampung Tua. }\end{array}$ \\
\hline Financial resources & $\begin{array}{l}\text { CSR programs from companies } \\
\text { that carry out business } \\
\text { activities in and around Batu } \\
\text { Besar Village. }\end{array}$ & $\begin{array}{l}\text { The community is directed and } \\
\text { guided to make community } \\
\text { empowerment programs according } \\
\text { to local resources and potential. }\end{array}$ \\
\hline
\end{tabular}




\begin{tabular}{|c|c|c|}
\hline Kind of potential & Present condition & Development opportunities \\
\hline & & $\begin{array}{l}\text { CSR funds are actually channeled } \\
\text { into programs that are in } \\
\text { accordance with the needs of the } \\
\text { community and the surrounding } \\
\text { environment and are } \\
\text { empowerment that supports } \\
\text { sustainable development. }\end{array}$ \\
\hline Public infrastructure & $\begin{array}{l}\text { Hang Nadim International } \\
\text { Airport. } \\
\text { Gelora Citramas stadium. }\end{array}$ & $\begin{array}{l}\text { Well cared for and managed as vital } \\
\text { access for the community. } \\
\text { It is well cared for and managed so } \\
\text { that all levels of society can access it } \\
\text { as a means of sports training and } \\
\text { support the progress of local } \\
\text { football clubs. }\end{array}$ \\
\hline
\end{tabular}

(Source: Report the Social Mapping of Pertamina Aviation Hang Nadim Batam, 2017)

Based on the table above shows that in fulfilling its Social responsibility, Pertamina Aviation Hang Nadim Batam, as a national energy corporate in Indonesia, created a CSR program called "Desa Berdikari", located in Kampung Tua, Batu Besar Village Nongsa District, Batam. CSR program that have been carried out by Pertamina Aviation Hang Nadim Batam in supporting sustainable development in Batam City in accordance with the potential of the area, such as: empowerment of micro knitting business groups, empowerment of business groups utilizing gonggong shells, welding business groups, and development of posyandu.

The findings show that the understanding of corporate responsibility has evolved from being limited to making profits into a broader set of responsibilities, namely the belief that the primary responsibility of the corporate is to generate shared value (Agudelo et all, 2019). This empowerment program was held as a form of awareness of Pertamina Aviation Hang Nadim Batam, that the CSR program is now a central issue for the growth and sustainability of positive synergy between the corporate, government and the surrounding community in Batu Besar Village Nongsa District, Batam. The implementation of the CSR program will improve the quality "corporate" that creates a conducive environment, this quality culture sees how the organizational values pay attention to the interactions between the corporate and the community (Habibie, 2019). 


\section{Methods}

In this study, author used qualitative research with descriptive methods to explore facts or phenomena (Creswell, 2014). Descriptive-analytic research is used as a type of research that uses a pattern of depicting empirical facts and relevant arguments to examine the specific role of corporate social responsibility by developing regional potential by Pertamina Aviation Hang Nadim entitled "Desa Berdikari" in Batu Besar Village Nongsa District, Batam. Descriptive-analytic research is intended to provide an overview of the phenomena relevant to this research. This qualitative research emphasizes deeper thinking and is based on social phenomena or the paradigm of social facts. This type of research is more sensitive and able to adapt to the qualitative methods adopted by this phenomenon.

\section{Result and Discussion}

\section{Program Corporate Social Responsibility Pertamina Aviation Hang Nadim Batam}

Aircraft refueling depot or called DPPU is a network of aviation fuel business services or aviation business lines, both domestically and overseas owned by PT. Pertamina. One of the DPPU operating units included in MOR I, namely DPPU Hang Nadim Batam or terms that the author use is Pertamina Aviation Hang Nadim Batam.

CSR is a mandatory obligation and is not categorized as something that can be selected in running a business (Tamvada, 2020). The implementation of CSR activities carried out by Pertamina Aviation Hang Nadim during the period June 2017 - June 2018 has realized 4 (four) CSR activities with the main headline "Desa Berdikari" all of which were held in Batu Besar Village Nongsa District in Batam. This community empowerment program consists of several activities, including empowerment programs that lead to increasing the capacity of community groups. Empowerment that has been carried out is in the form of:

1. Training and business management of knitting business groups

To develop business potential and opportunities for housewives in Batu Besar Village, Batam City, Pertamina Aviation Hang Nadim implements a knitting training program which is attended by 11 people who live in the local area. CSR program by Pertamina Aviation Hang Nadim is targeting the development of new and independent entrepreneurs resulting from the formation of orders for less productive human resources to be more creative, innovative, and cooperative by raising the types of local wisdom in each product produced. However, the 
number of participants who participated in this knitting training was not in accordance with the CSR work plan target of Pertamina Aviation Hang Nadim Batam as many as 20 fostered participants. This is due to the lack of interest in the local community towards this training program and a problem in implementing this program. Community participation in the implementation of CSR programs is influenced by internal factors that come from within the community itself including individual characteristics, willingness and abilities. Meanwhile, external factors that can encourage or hinder participation, including the role of stakeholders and opportunities (Nurbaiti, 2017). During the period October 2017 - February 2018, beneficiaries received training, business facilities and business assistance in the form of:

- Kniting skills training through the practice of making knit products, including flower brooches, cellphone bags and knit of strimin cloth images.

- Distribution of business facilities and infrastructure assistance in the form of knitting equipment and sewing machines to support the production process of the knitting group business.

- Business assistance that initiates the institutional function and role of the knitting business group in the production and marketing of products produced by its members to the market.

\section{Figure 2.}

The results of the knitting business

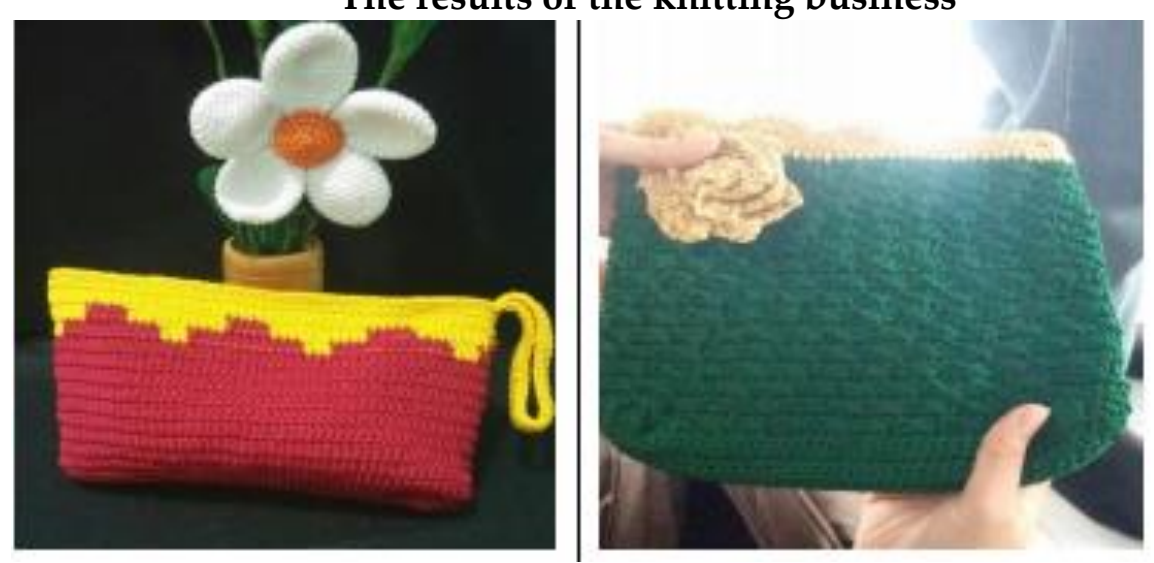

(Source: Accountability report of Pertamina Aviation Hang Nadim, 2018) 
Table 2.

Realization of CSR Funds of training and business management of knitting business groups

\begin{tabular}{ccccccc}
\hline & \multicolumn{5}{c}{ Year } \\
\cline { 2 - 6 } Program & Fund & Result (\%) & $\begin{array}{c}\text { Number of } \\
\text { recipients }\end{array}$ & Fund & Result (\%) & $\begin{array}{c}\text { Number } \\
\text { of } \\
\text { recipients }\end{array}$ \\
\cline { 2 - 7 } & 75.000 .000 & 100 & 11 person & 57.000 .000 & 50 & 11 person \\
\hline $\begin{array}{c}\text { Training of } \\
\text { Knitting }\end{array}$ & & & & & \\
\hline
\end{tabular}

(Source: Accountability report CSR program of Pertamina Aviation Hang Nadim, 2018)

Based on the table above shows that in the training and business management activities of the knitting business group in 2017 Pertamina Aviation Hang Nadim in the amount of Rp. 75,000,000 with the realization of Rp. 75,000,000, - or 100\% with a total of 11 housewives as beneficiaries. The fund realization in 2018 was Rp. 57,000,000 with the realization of Rp. $28,500,000$, - or $50 \%$ with a total of 11 housewives as beneficiaries.

Table 3.

The impact of CSR program of training and business management of knitting business groups

\begin{tabular}{ccccc}
\hline Program & Goal & $\begin{array}{c}\text { Indicator of } \\
\text { activity }\end{array}$ & $\begin{array}{c}\text { Target for } \\
\mathbf{2 0 1 8}\end{array}$ & $\begin{array}{c}\text { Implementation } \\
\text { Schedule }\end{array}$ \\
\hline Training of & $\begin{array}{c}\text { Increased per capita } \\
\text { income of the } \\
\text { Knitting } \\
\text { community / assisted } \\
\text { community groups. }\end{array}$ & $\begin{array}{c}\text { The number of } \\
\text { assisted group } \\
\text { housewives } \\
\text { received training } \\
\text { capacity }\end{array}$ & 20 person & May-July \\
& & & \\
\hline
\end{tabular}

(Source: Accountability report CSR program of Pertamina Aviation Hang Nadim, 2018)

Based on the table above, it can be seen that the targets in training activities and business management of this knitting business group are able to increase per capita income of the community / assisted community group. The indicator in this activity is the increasing number of assisted group housewives who receive training capacity. In 2018, the implementation of this activity was carried out in May 2018, with a target of 20 housewives as beneficiaries, but seen from the realization of the budget in the previous table, the beneficiaries of this activity were only 11 housewives as beneficiaries.

2. Utilization of gonggong skin into local souvenir handicraft products 
The Gonggong handicraft business group empowerment program is manifested by the CSR of Pertamina Aviation Hang Nadim through the management of shell waste which is developed as a unique and beautiful handicraft so that it has a selling value. This CSR program is carried out in the form of providing business capital, business facilities, product development and business assistance for local craftsmen groups. This program aims to improve the competence and capacity of beneficiaries in carrying out their economic business activities, as well as to increase business income.

Assistance was given to the Sanggar Melati business group located at RT.04/RW.01 Batu Besar Village Nongsa District Batam City. This group focuses on making handicrafts from gonggong shells which are characteristic of the Riau Islands. Aside from that to capital assistance to ten members of the Sanggar Melati business group, training and practice of making several products such as gonggong skin flowers and gonggong key chains have been used as souvenirs at various weddings in Batam City. In addition, with facilitation from Pertamina Aviation Hang Nadim, the products produced by Sanggar Melati have been routinely included in various regional handicraft exhibition events held inside and outside Batam City. This program shows that the corporate's involvement in carrying out CSR activities is not only in the economic sector, but the corporate is also able to be involved in preserving the environment in the community (Haris, 2017).

\section{Figure 3.}

The process of utilization gonggong skins to become local souvenir handicraft products

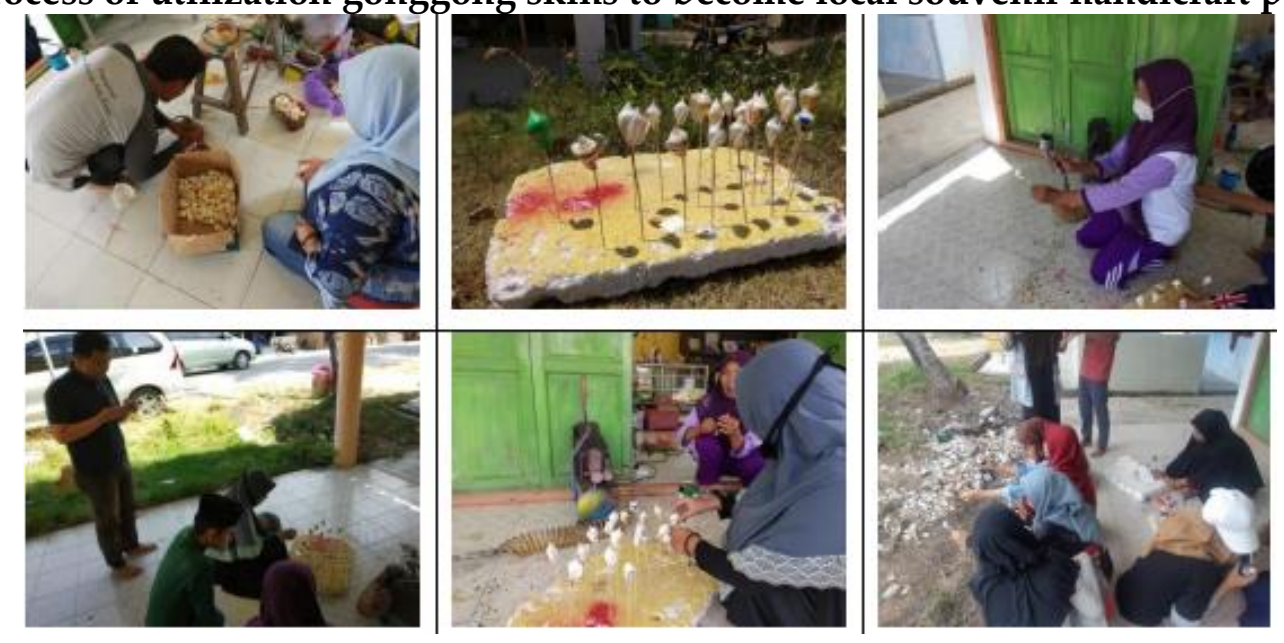

(Source: Accountability report of Pertamina Aviation Hang Nadim, 2018) 
Table 4.

Realization of CSR Funds of utilization

of gonggong skin into local souvenir handicraft products

\begin{tabular}{|c|c|c|c|c|c|c|}
\hline \multirow{3}{*}{ Program } & \multicolumn{6}{|c|}{ Year } \\
\hline & \multicolumn{3}{|c|}{2017} & \multicolumn{3}{|c|}{2018} \\
\hline & Fund & Result (\%) & $\begin{array}{c}\text { Number of } \\
\text { recipients }\end{array}$ & Fund & Result (\%) & $\begin{array}{c}\text { Number } \\
\text { of } \\
\text { recipients }\end{array}$ \\
\hline Training of & & & & & & \\
\hline $\begin{array}{c}\text { Gonggong } \\
\text { craft }\end{array}$ & 125.000 .000 & 100 & 15 person & 66.000 .000 & 50 & 15 person \\
\hline
\end{tabular}

(Source: Accountability report CSR program of Pertamina Aviation Hang Nadim, 2018)

Based on the table above, it shows that in the activity of utilizing gonggong skin to become local souvenir handicraft products in 2017, Pertamina Aviation Hang Nadim in the amount of Rp. $125,000,000$ with the realization of Rp. 125,000,000, - or $100 \%$ with a total of 15 beneficiaries. The fund realization in 2018 was Rp. 66,000,000 with the realization of Rp. $33,000,000,-$ or $50 \%$ with a total of 15 beneficiaries.

Table 5.

The impact of CSR program of utilization of gonggong skin into local souvenir handicraft products

\begin{tabular}{ccccc}
\hline Program & Goal & $\begin{array}{c}\text { Indicator of } \\
\text { activity }\end{array}$ & $\begin{array}{c}\text { Target for } \\
\mathbf{2 0 1 8}\end{array}$ & $\begin{array}{c}\text { Implementation } \\
\text { Schedule }\end{array}$ \\
\hline $\begin{array}{c}\text { Training of } \\
\text { Gonggong } \\
\text { craft }\end{array}$ & $\begin{array}{c}\text { Increased per capita } \\
\text { income of the } \\
\text { community / assisted } \\
\text { community groups. }\end{array}$ & $\begin{array}{c}\text { Percentage } \\
\text { increase in } \\
\text { average monthly } \\
\text { income }\end{array}$ & $10 \%$ & April-July \\
\hline
\end{tabular}

(Source: Accountability report CSR program of Pertamina Aviation Hang Nadim, 2018)

The table above shows, it can be seen that the targets in the activity of using gonggong skins into local souvenir handicraft products are able to increase the per capita income of the community / assisted community groups. The indicator in this activity is the percentage increase in the average monthly income. In 2018, this activity will be implemented from April to July 2018 , with a target of $10 \%$ increase in average monthly income. One of the good effects of CSR is that it can improve social welfare (Fukuda and Ouchida, 2020).

3. Training of certified welding for a productive workforce

Commitment of Pertamina Aviation Hang Nadim in developing the competence of local human resources in the era of ASEAN free competition was transformed through a welding 
skills training program for 5 (five) youth drop out of school delegation from Batu Besar Village. Welding training was held in October - November 2017 at the PT KIAT Global Batam Training Center with the material provided, namely the 3G Shield Metal Arc Welding (SMAW) welder engineering which is widely applied by various manufacturing industries spread across Batam City.

This technique is a basic skill that every professional welder must have. The target of this program is youth dropping out of school and the target to be achieved for participants who take this training is 20 young people, this is a problem during program implementation because only 5 youths are interested in this program. The small number of participants who took part in this training was due to the limited acceptance of corporate employees in Batam in the field of welding. So that the assumption of youth regarding the opportunity to work in companies after receiving this training is still very small.

All participants were declared to have passed the training program and received a certificate of proficient skills in SMAW 3G welder engineering operations. New skills acquired as a result of the distribution of CSR by Pertamina Aviation Hang Nadim besides being able to be used to work in manufacturing industries in Batam City and its surroundings; competency certificates obtained after graduation from the training program that the participants can be used as provisions to become independent welding entrepreneurs.

Therefore, through the implementation of independent welding efforts by youth in their respective areas of domicile, a process of knowledge transfer can be created, the benefits of which can be felt by other young people towards reducing the unemployment rate in the productive workforce in Batam City. Until now, the initiative of Pertamina Aviation Hang Nadim through CSR to youth of the productive workforce has shown encouraging developments where 1 (one) welding workshop has been established which is managed by alumni beneficiaries in Batu Besar Village. 
Figure 4.

The process of training 3G SMAW stainless steel

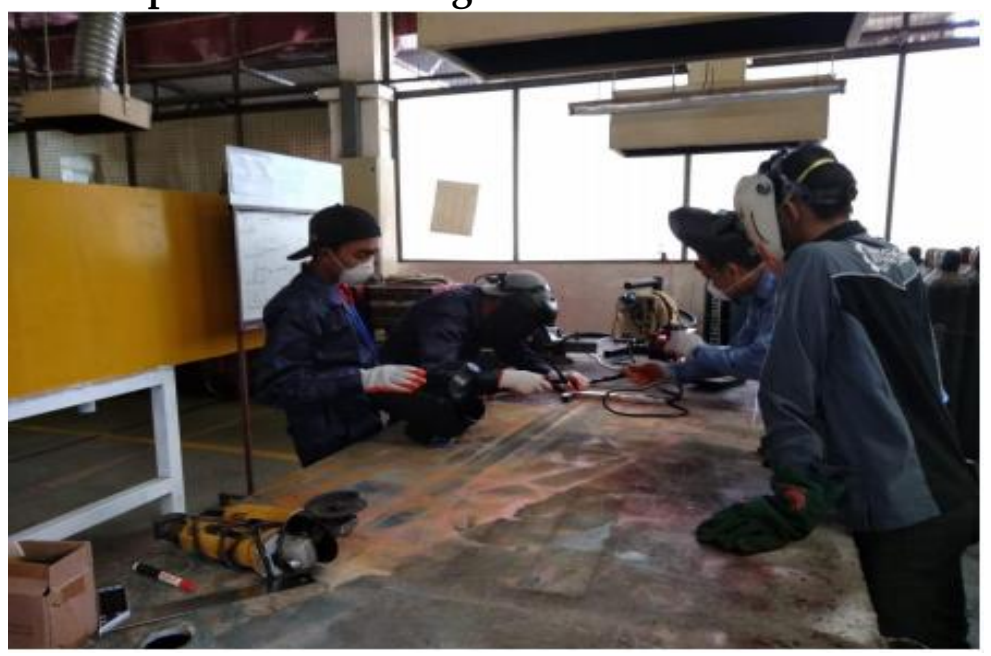

(Source: Accountability report of Pertamina Aviation Hang Nadim, 2018)

Table 6.

Realization of CSR Funds of training of certified welding for a productive workforce

\begin{tabular}{ccccccc}
\hline & \multicolumn{5}{c}{ Year } \\
\cline { 2 - 6 } Program & Fund & Result (\%) & $\begin{array}{c}\text { Number of } \\
\text { recipients }\end{array}$ & Fund & Result (\%) & $\begin{array}{c}\text { Number } \\
\text { of } \\
\text { recipients }\end{array}$ \\
\cline { 2 - 7 } & 100.000 .000 & 100 & 10 person & 50.000 .000 & 50 & 10 person \\
\hline $\begin{array}{c}\text { Training of } \\
\text { Welding }\end{array}$ & 10018 & & & & \\
\hline
\end{tabular}

(Source: Accountability report CSR program of Pertamina Aviation Hang Nadim, 2018)

Based on the table above shows that in the certified welding training activities for the productive workforce in 2017 Pertamina Aviation Hang Nadim in the amount of Rp. $100,000,000$ with the realization of Rp. 100,000,000, - or 100\% with a total of 10 beneficiaries. The fund realization in 2018 was Rp. 50,000,000 with the realization of Rp. 25,000,000, - or 50\% with a total of 10 beneficiaries.

Table 7.

The impact of CSR program of training of certified welding for a productive workforce

\begin{tabular}{ccccc}
\hline Program & Goal & $\begin{array}{c}\text { Indicator of } \\
\text { activity }\end{array}$ & $\begin{array}{c}\text { Target for } \\
\mathbf{2 0 1 8}\end{array}$ & $\begin{array}{c}\text { Implementation } \\
\text { Schedule }\end{array}$ \\
\hline Training of & $\begin{array}{c}\text { Increased per capita } \\
\text { income of the } \\
\text { Welding }\end{array}$ & $\begin{array}{c}\text { Number of out of } \\
\text { school / } \\
\text { community / assisted } \\
\text { unemployed youth } \\
\text { who received }\end{array}$ & 20 person & May-August \\
\hline
\end{tabular}


welding training or

certification

(Source: Accountability report CSR program of Pertamina Aviation Hang Nadim, 2018)

Based on the table above, it can be seen that the targets in the certified welding training activities for the productive workforce are able to increase per capita income of the community / assisted community groups. The indicator for this activity is the increasing number of youth dropping out of school / unemployed to receive welding training or certification. In 2018, the implementation of this activity was carried out in May 2018, with a target of 20 school dropouts / unemployed youth as beneficiaries. However, seen from the budget realization in the previous table, the beneficiaries of this activity were only 10 out of school / unemployed youth as beneficiaries. The insufficient number of participation will greatly impact the sustainability of each program implemented by the corporate. Its mean participation will influence a corporate's decision making (Muhdar, 2016).

4. Education of posyandu development

Specifically, this program is focused on the Under-five Family Development scheme which aims to help fulfill nutrition and to determine children's development properly. This activity was carried out in the Teluk Bakau area, Batu Besar Village Nongsa District Batam City. Duration of the implementation during the period October 2017 - February 2018, it has effectively and efficiently promoted Clean and Healthy Living Behavior (PHBS) with 7 (seven) cadres from the local area. The number of cadres was a problem that was found during the program implementation, because it was not in accordance with the target in the CSR work plan of Pertamina Aviation Hang Nadim which recorded as many as 50 cadres. The Education of posyandu development program also includes carrying out activities for weighing, measuring height, immunization, consultation with midwives and providing additional food such as green bean porridge, eggs, bananas, oranges, milk and biscuits for 3 months (November 2017 - January 2018 ) with an average number of participants of 243 people per month. 
Figure 5.

The process of education of posyandu development

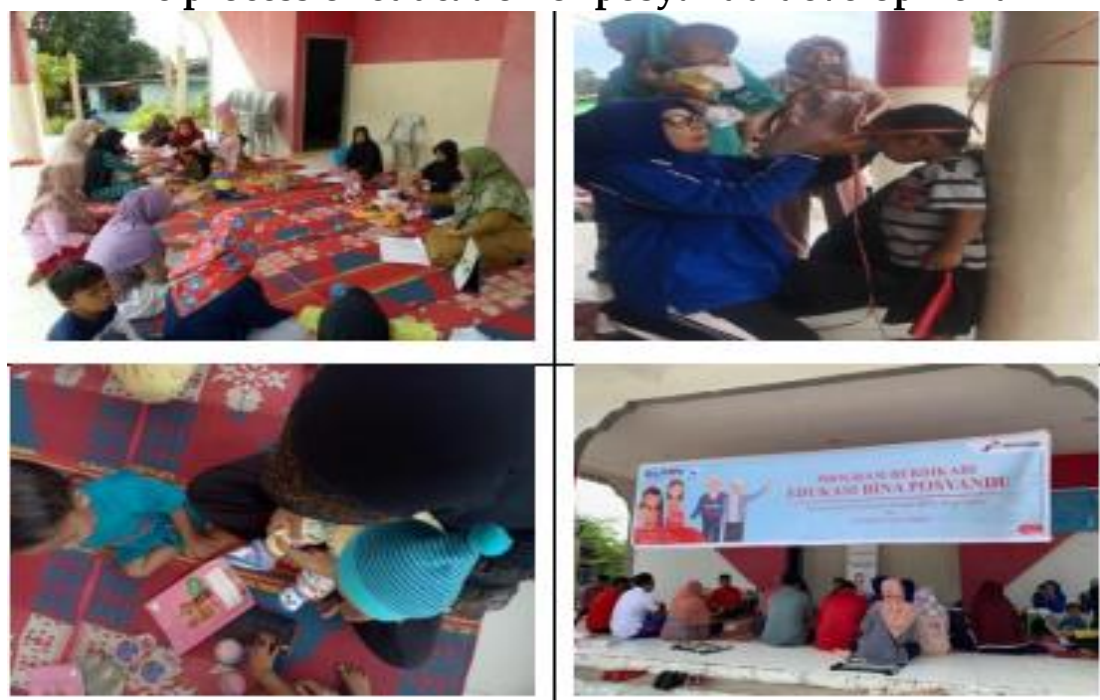

(Source: Accountability report of Pertamina Aviation Hang Nadim, 2018)

Table 8.

Realization of CSR Funds of education of posyandu development

\begin{tabular}{|c|c|c|c|c|c|c|}
\hline \multirow{3}{*}{ Program } & \multicolumn{6}{|c|}{ Year } \\
\hline & \multicolumn{3}{|c|}{2017} & \multicolumn{3}{|c|}{2018} \\
\hline & Fund & Result (\%) & $\begin{array}{l}\text { Number of } \\
\text { recipients }\end{array}$ & Fund & $\begin{array}{c}\text { Result } \\
(\%)\end{array}$ & $\begin{array}{l}\text { Number of } \\
\text { recipients }\end{array}$ \\
\hline $\begin{array}{c}\text { Education of } \\
\text { posyandu } \\
\text { development }\end{array}$ & 85.000 .000 & 100 & $\begin{array}{c}243 \text { under- } \\
\text { five }\end{array}$ & 61.000 .000 & 50 & $\begin{array}{l}122 \text { under- } \\
\text { five }\end{array}$ \\
\hline
\end{tabular}

(Source: Accountability report CSR program of Pertamina Aviation Hang Nadim, 2018)

Based on the table above, it shows that in the education of posyandu development in 2017 Pertamina Aviation Hang Nadim in the amount of Rp. 85,000,000 with the realization of Rp. 85,000,000, - or 100\% with a total of 243 beneficiaries. The fund realization in 2018 was Rp. $61,000,000$ with the realization of Rp. 30,500,000, - or 50\% with a total of 122 beneficiaries.

Table 9.

The impact of CSR program of education of posyandu development

\begin{tabular}{ccccc}
\hline Program & Goal & $\begin{array}{c}\text { Indicator of } \\
\text { activity }\end{array}$ & $\begin{array}{c}\text { Target for } \\
2018\end{array}$ & $\begin{array}{c}\text { Implementation } \\
\text { Schedule }\end{array}$ \\
\hline $\begin{array}{c}\text { Education of } \\
\text { posyandu }\end{array}$ & $\begin{array}{c}\text { Increased the degree of } \\
\text { public health. }\end{array}$ & $\begin{array}{c}\text { The number of } \\
\text { posyandu cadres } \\
\text { who received } \\
\text { training }\end{array}$ & 20 cadres & April-July \\
& pelopment & & & \\
\hline
\end{tabular}

(Source: Accountability report CSR program of Pertamina Aviation Hang Nadim, 2018) 
Based on the table above, it can be seen that the targets in the education of posyandu development can improve the health status of the community. The indicator for this activity is the increasing number of posyandu cadres who have received training. In 2018, the implementation of this activity will be held from April to July 2018, with a target of 50 posyandu cadres as beneficiaries.

Based on the four (4) tables for the realization of the CSR program fund above, it is one proof that the corporate is serious about helping the people of Batu Besar Village Nongsa District in Batam. The funds are used by the local community to meet needs such as facilities for embroidering equipment, sewing machines and providing business capital, business facilities, product development and business assistance for craftsmen groups, training in welding skills and to help fulfill nutrition. Socially responsible behavior is a topic of fundamental analysis in Economics and Finance which scientists are beginning to approach in a systematic and integrated manner. Such behavior is an important part of the market mechanism and the economy in general (Gomes, 2020).

However, if it is seen that the fund above has decreased per activity carried out from the previous year, the results obtained by the corporate have also decreased significantly from $100 \%$ to $50 \%$. However, for fund recipients, in some activities the number was still the same as in the previous year, while in the education of posyandu development had decreased by 121 under-five. The decrease in budget realization and the number of recipients was based on the lack of public participation in this activity. The implementation of CSR can be interpreted as "CSR interaction", which is creating social change and increasing the dynamics between the corporate and local communities and stakeholders (Fordham and Robinson, 2018).

\section{Conclusion}

The CSR program of Pertamina Aviation Hang Nadim Batam has provided many benefits and positive impacts in developing regional potential and increasing community capacity with the theme "Desa Berdikari". The independent knitting program has provided benefits in enhancing the performance of micro-knitting business groups, through coaching and mentoring independent knitting business groups that have produced unique knitted 
products that attract tourists. Even though some activities have not yet reached the target according to the planned CSR program of Pertamina Aviation Hang Nadim, in the future this program can be sustainable so that the beneficiaries of this activity will increase. The gonggong shell utilization program has helped the community in preserving the environment by utilizing the gonggong shell into attractive creative products. The education of posyandu development program has had a positive impact on posyandu management and has led to an independent posyandu. Welding training program and certified advanced skills in the 3G SMAW welder engineering operations. New skills acquired as a result of distributing CSR by Pertamina Aviation Hang Nadim apart from being used to work in manufacturing industries in Batam City and its surroundings; competency certificates obtained after graduating from the training program participated in by participants can also be used as provisions to become independent welding entrepreneurs. Even though in some activities they have not reached the target according to the CSR program plan of Pertamina Aviation Hang Nadim, we hope this program can be sustainable so that the beneficiaries this activity is increasing.

“Desa Berdikari" programs that have been implemented are able to provide business opportunities and reduce unemployment in the community. In the future, Pertamina Aviation Hang Nadim Batam will remain focused on developing regional potential in Batam City through the CSR program and can help the government in increasing community capacity.

\section{References}

Agudelo, M. A. L., Jóhannsdóttir, L., \& Davídsdóttir, B. (2019). A Literature Review Of The History and Evolution Of Corporate Social Responsibility. International Journal of Corporate Social Responsibility, 4(1), 1.

Anto, A. (2018). Program Corporate Social Responsibility Dalam Perspektif Indeks Kepuasan Publik Di Riau. Sosio Konsepsia, 6(1), 90-109.

Creswell, J. W. (2014). Metode Penelitian Kualitatif \& Desain Riset. Bandung: Penerbit Alfabeta, 161.

Fordham, A. E., \& Robinson, G. M. (2018). Mapping Meanings Of Corporate Social Responsibility-An Australian Case Study. International Journal of Corporate Social Responsibility, 3(1), 14. 
Fukuda, K., \& Ouchida, Y. (2020). Corporate Social Responsibility (CSR) and The Environment: Does CSR Increase Emissions?. Energy Economics, 92, 104933.

Garcia-Chiang, A. (2018). Corporate Social Responsibility In The Mexican Oil Industry: Social Impact Assessment As A Tool For Local Development. International Journal of Corporate Social Responsibility, 3(1), 15.

Gomes, O. (2020). Optimal Growth Under Socially Responsible Investment: A Dynamic Theoretical Model Of The Trade-Off Between Financial Gains And Emotional Rewards. International Journal of Corporate Social Responsibility, 5(1), 1-17

Habibie, D. K., \& Putri, A. U. (2019, November). Corporate University and Development of HR Street-Level Bureaucracy. In Iapa Proceedings Conference (pp. 346-456).

Haris, A. M., \& Purnomo, E. P. (2017). Implementasi CSR (Corporate Social Responsibility) PT. Agung Perdana Dalam Mengurangi Dampak Kerusakan Lingkungan. Journal of Governance and Public Policy, 3(2), 203-225.

Mashur, D. (2019). Best Practice Program Corporate Social Responsibility (CSR) PT. Pertamina RU II Production Sungai Pakning. Iapa Proceedings Conference,, 230-244. doi:10.30589/proceedings.2019.229

Muhdar, M., Jamaludin, J., \& Irwansyah, I. (2016). Partisipasi Masyarakat dalam Program Corporate Social Responsibility PT. Arutmin Nort Pulau Laut Coal Terminal Kotabaru (Studi Tentang Program Koperasi Serba Usaha Madani Kotabaru). Jurnal Bisnis dan Pembangunan, 1(1).

Nainggolan, A. F., \& Rusli, Z. (2015). Strategi Pelaksanaan Program Corporate Social Responsibility (CSR) Pada PT. Riau Andalan Pulp and Paper Di Kabupaten Pelalawan. Jurnal Online Mahasiswa Universitas Riau, 2(1), 1-10.

Nurbaiti, S. R., \& Bambang, A. N. (2017). Faktor-faktor yang Mempengaruhi Partisipasi Masyarakat dalam Pelaksanaan Program Corporate Social Responsibility (CSR). In Proceeding Biology Education Conference (Vol. 14, No. 1, pp. 224-228).

Sukmana, F. H. (2019). Potensi Program Csr untuk Mendukung Pembangunan di Kabupaten Lombok Utara. Media Bina Ilmiah, 13(9), 1573-1582.

Tamvada, M. (2020). Corporate Social Responsibility and Accountability: A New Theoretical Foundation For Regulating CSR. International Journal of Corporate Social Responsibility, $5,1-14$. 
Wirawati, N. G. P dan I P. I. Wijaya. (2019). Good Corporate Governance sebagai Pemoderasi Pengaruh Profitabilitas dan Corporate Social Responsibility pada Nilai Perusahaan. EJurnal Akuntansi Universitas Udayana Bali, 16(1), 156-182. 